\title{
PostGIS pro vývojáře
}

\author{
Pavel Stěhule \\ Department of Mapping and Cartography, Faculty of Civil Engineering \\ Czech Technical University in Prague \\ stehule kix.fsv.cvut.cz
}

Klíčová slova: Database systems, GIS, development

\begin{abstract}
Abstrakt
Systémy GIS první generace ukládaly svá data do souborů v proprietárních formátech. Dalši generace těchto systémů dokázaly spolupracovat s databázemi (zejména čerpat data s databází). Soudobé GIS systémy se již zcela spoléhaji na databáze. Tyto požadavky GIS systémů musely reflektovat databázové systémy. Nejstarši SQL systémy vůbec s prostorovými daty nepočítaly.
\end{abstract}

\section{Úvod}

Až standard ANSI SQL2000 v části věnované podpoře multimediálních dat obsahuje popis prostorových (spatial) dat. Z komerčních databází je na prvním místě, co se týče podpory prostorových dat, databázový systém fy. Oracle. Počínaje verzí Oracle 7 existuje rozširrení Oracle, samostatně distribuované, řešící podporu prostorových dat. Toto rozššřrení se nazývá Oracle spatial. Odpovědí o.s. světa byla implementace podpory prostorových dat pro RDBMS PostgreSQL a to tak, jak předpokládá standard OpenGIS.

Jednou z charakteristik PostgreSQL je právě jeho rozšiřitelnost. V PostgreSQL lze relativně jednoduše navrhnout vlastní datové typy, vlastní operace a operandy nad těmito typy. Touto vlastností byl systém PostgreSQL mezi o.s. databázovými systémy výjimečný. Proto celkem logicky byl PostgreSQL použit pro o.s. implementaci standardu OpenGIS. Ćást standardu OpenGIS (chronologicky předchází SQL2000) je zaměřena na SQL databáze, které by měly sloužit jako uložiště prostorových dat. Vychází z SQL92 rozšířeného o geometrické typy (SQL92 with Geometry Types), definuje metadata popisující funkcionalitu systému co se týká geometrických dat, a definuje datové schéma. Databáze, jejichž datový model respektuje normu OpenGIS, může sloužit jako datový server libovolné GIS aplikaci, která vychází z tohoto standardu. Díky tomu může, v celé řadě případi̊, PostgreSQL zastoupit komerční db systémy. Implementace standardu OpenGIS pro PostgreSQL se nazývá PostGIS. PostgreSQL základní geometrické typy má, úkolem PostGISu je hlavně jejich obalení do specifického (určeného normou) datového modelu. SQL/MM-Spatial sice vychází z OpenGIS nicméně není kompatibilní. PostGIS je certifikován pro OpenGIS, částečně také implementuje SQL/MM. 
PostGIS obsahuje:

- nové datové typy (geometry),

- nové operátory (\&\& průnik, @kompletně obsažen),

- nové funkce (distance, transform),

- nové tabulky (Geometry_columns, Spatial_ref_sys) slouží jako systémové tabulky, poskytují prostor pro metadata.

Standard OpenGIS je množina dokumentů detailně popisující aplikační rozhraní a datové formáty v oblasti GIS systémů. Tato dokumentace je určena vývojářům a jejím cílem je dosažení interoperability aplikací vyvíjených členy konsorcia Open Geospatial Consortium (www stránky OGC). Oblast, kterou pokrývá PostGIS je popsána v dokumentu "OpenGIS@ Simple Features Specification For SQL"

Názvy datových typů v SQL/MM odvozených z OpenGISu vznikly spojením prefixu ST (spatial type) a názvu datového typu v OpenGISu. OpenGIS je obecnější, počítá s minimálně dvěma variantami implementace geometrických typů, a k tomu potřebnému zázemí. SQL/MM-Spatial se dá s jistou mírou tolerance chápat jako podmnožina OpenGISu.

\section{Implementace vlastních funkcí v PostgreSQL}

Vzhledem k faktu, že vlastní datové typy lze implementovat pouze $\mathrm{v}$ prg. jazyce $\mathrm{C}$ a že PostGIS je implementován v C, bude popsán návrh modulu pouze s využitím jazyka C.

Při návrhu funkcí v C se prakticky všude používají makra z PostgreSQL knihovny. Důvodů je několik:

- používání univerzálního typu Varlena pro typy s variabilní délkou, který je v případě, že je delší než $2 \mathrm{~K}$ transparentně (jak pro uživatele, tak pro vývojáře) komprimován.

- odlišný způsob předávání parametrům (v PostgreSQL nepřímo prostřednictvím určené hodnoty typu struct obsahující ukazatel na pole parametrů, pole s informací, který parametr je NULL, a počtem parametrů).

- tento způsob volání není závislý na programovacím jazyku C

Ukázka implementace funkce concat_text spojující dva řetězce dohromady:

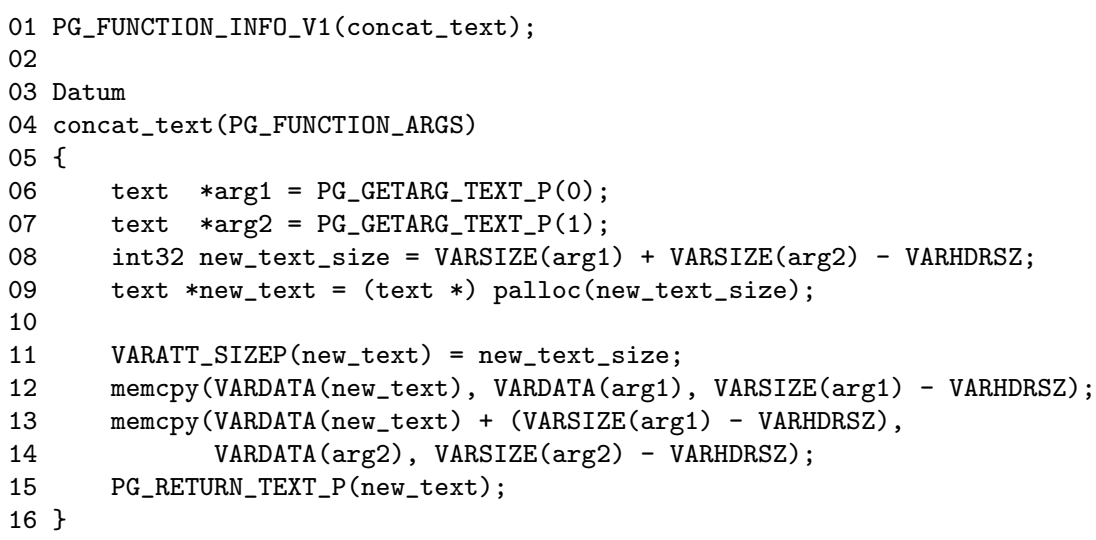


Komentáře:

01 Registrace funkce s volací konvencí 1.

03 Každá funkce dosažitelná z SQL musí vracet univerzální datový typ Datum (společný typ pro datové typy s fixní velikostí (menší než 64bite) a datový typ varlena).

06 Získání prvního parametru (resp. ukazatele na něj a korektní přetypování, případně dekomprimace).

07 Získání prvního parametru (resp. ukazatele na něj a korektní přetypování, případně dekomprimace).

08 Datový typ varlena je podobný stringu v Pascalu, první čtyři byte obsahují údaj o délce s rozdílem, že údaj obsahuje velikost celé hodnoty včetně záhlaví. Velikost hlavičky je uložena v konst. VARHDRSZ. Výpočet velikosti vrácené hodnoty typu datum (součet velikostí obou řetězců + velikost hlavičky).

09 PostgreSQL má vlastní správu paměti, tudíž se pamět nealokuje voláním funkce malloc, ale palloc. PostgreSQL přiděluje pamět z tzv. pamětových kontexti̊ (persistentní, transakce, volání funkce). Při dokončení operace se uvolňuje odpovídající pamětový kontext. Explicitní volání pfree má smysl jen u funkcí, které by bez explicitního uvolnění paměti si nárokovali př́liš paměti. Použití pamětových kontextů snižuje riziko tzv. memory leaku, tj. že vývojář zapomene vrátit alokovanou pamět. Také snižují náročnost vrácení paměti. Místo několikanásobného uvolnění malých bloků paměti se volá jednorázová operace. Dalším př́ijemným efektem je nižší fragmentace paměti.

15 Přetypování z typu text na datum (případná komprimace).

Každá interní funkce se musí před vlastním použitím zaregistrovat pro její použití v SQL.

01 CREATE FUNCTION concat_text (text, text) RETURNS text

02 AS 'DIRECTORY/funcs', 'concat_text'

03 LANGUAGE C STRICT;

Komentáře:

01 Funkce concat_text má dva parametry typu text a vrací text.

02 Tuto funkci PostgreSQL nalezne v knihovně (souboru) 'DIRECTORY/funcs' pod názvem 'concat_text'.

03 Jedná se o binární knihovnu. V případě, že jeden parametr je NULL, výsledkem volání funkce je hodnota NULL (atribut STRICT).

Pro volání existujících PostgreSQL funkcí (pod volající konvencí 1) musíme použít specifický způsob jejich volání, resp. předání parametrů. Často používanou funkcí je textin, což je funkce, která slouží pro převod z-řetězce (klasického řetězce $\mathrm{v}$ jazyce $\mathrm{C}$ ukončeného nulou) na řetězec typu varlena. Následující funkce vrátí konstantní řetězec "Hello World!".

01 PG_FUNCTION_INFO_V1(hello_world);

02

03 Datum

04 hello_word(PG_FUNCTION_ARGS)

05\{

06 PG_RETURN_DATUM (DirectFunctionCall1 (textin, CStringGetDatum("Hello World!")));

07 \} 
Komentáře:

06 CStringGetDatum provádí pouze přetypování

Bez použití funkce DirectFunctionCall1(1 na konci názvu funkce má význam jeden argument. Tato funkce existuje ve variantách pro jeden až devět argumentů.) by výše zmíněná funkce vypadala následovně (z ukázky je vidět předávání parametrů v V1 volající konvenci):

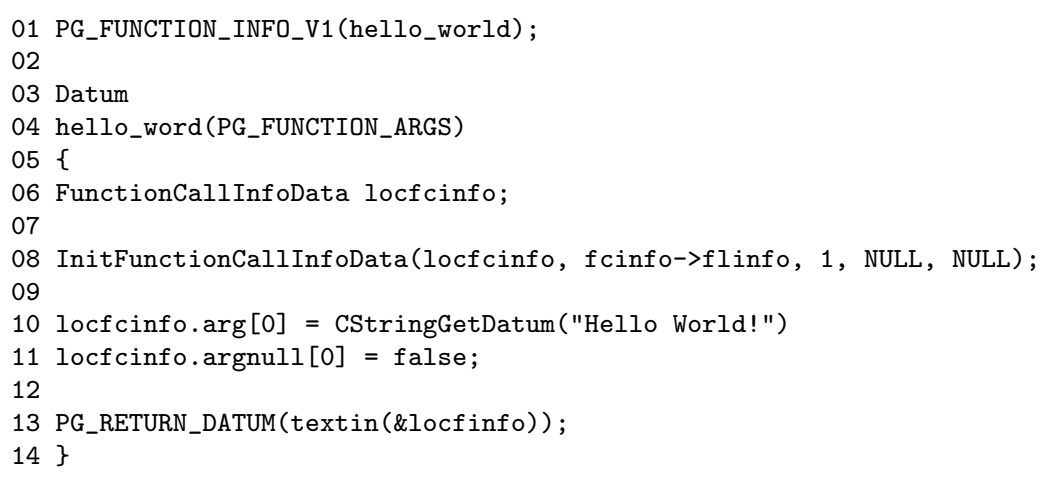

Komentáře:

08 Datová struktura locfcinfo je inicializována pro jeden argument.

13 Přímé volání funkce textin. Jelikož tato funkce vrací typ Datum, který je výsledný typ funkce hello_world, nedochází k přetypování.

\section{Implementace vlastních datových typů v PostgreSQL}

V PostgreSQL je každý datový typ určen svojí vstupní a výstupní, a sadou operátorů a funkcí, které tento typ podporují. Vstupní funkce je funkce, která převádí řetězec na binární hodnotu. Výstupní funkce inverzně převádí binární hodnotu na řetězec. Podporované operátory a funkce pak pracují s binární hodnotou. V případě vkládání nových záznamů se vstupní funkce volají automaticky, v případě výrazů je nutné v některých případech volat explicitní konverzi.

Explicitní konverze se v PostgreSQL provede třemi různými způsoby:

- zápisem typu následovaný řetězcem

- použitím ANSI SQL operátoru CAST

- použitím binárního operátoru pro přetypování '::' (není standardem)

Ukázka:

SELECT rodne_cislo '7307150xxx';

SELECT CAST ('730715xxx' AS rodne_cislo);

SELECT '730715xxx': :rodne_cislo;

OpenGIS, coby nezávislý standard, přidává vlastní způsob zápisu. V OpenGISu je počítáno i s variantou, že data jsou uložená textově, v př́ípadě že databázový systém nelze rozššririt o geometrické typy (což není př́ípad PostgreSQL). Nicméně PostGIS nepoužívá geometrické typy PostgreSQL. Typ se zapisuje přímo do řetězce následovaný vlastními daty, které jsou uzavřené v závorkách. Tento zápis se označuje jako 'Well-Known Text (WKT)'. Pro přečtení hodnoty tohoto typu se používá funkce GeometryFromText. 
Ukázka:

INSERT INTO SPATIALTABLE ( THE_GEOM, THE_NAME ) VALUES

( GeomfromText('POINT (-126.4 45.32)', 312), 'A Place');

Kromě textového formátu je v OpenGISu ještě definován binární formát 'Well-Know Binary (WKB)'. Konverzi z binárního formátu do textového (čitelná podoba) formátu provádí funkce asewkt (astext). Interně PostGIS ukládá data v binárním formátu WKB.

Pokud máme vstupní a výstupní funkci k dispozici, můžeme zaregistrovat nový datový typ př́íkazem CREATE TYPE.

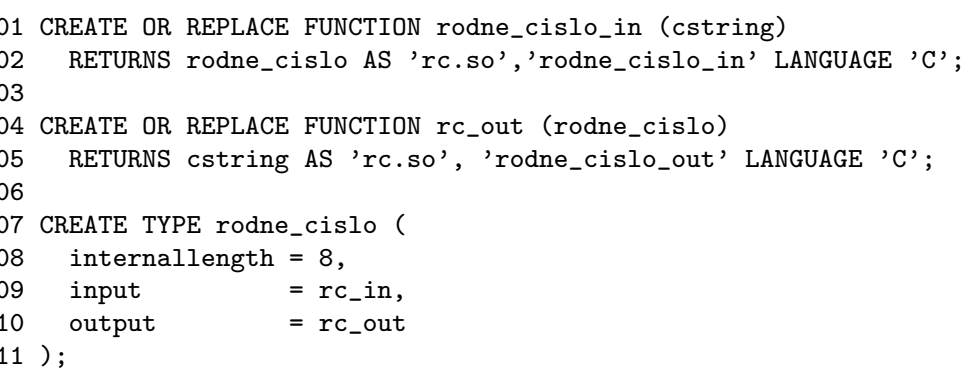

\section{Komentáře:}

08 Jedná se o datový typ s pevnou délkou osmi bajtů.

Pokud chceme datovým typ použít v databázi, musíme implementaci datového typu rozšíríit o implementaci základních binárních operátorủ. Poté bude možné použít vlastní datový typ v klauzuli WHERE a ORDER BY.

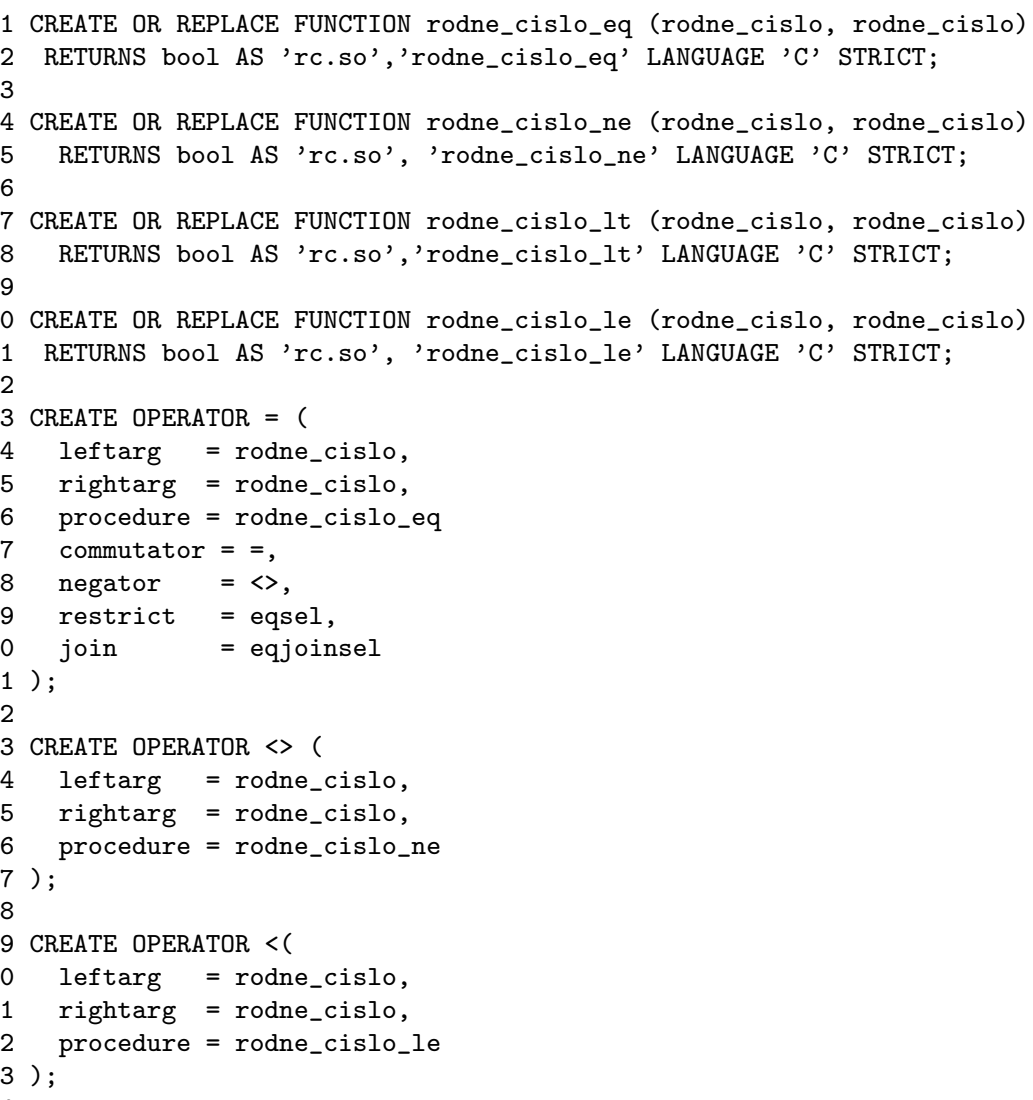




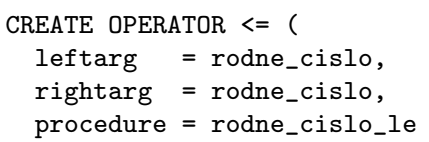

Komentáře:

13 Registrace binárního operátoru rovno.

14 Levý argument je typu rodné číslo.

15 Pravý argument je typu rodné číslo.

16 Název funkce, která zajištujuje operaci porovnání pro datový typ rodne_cislo.

17 Rovná se je komutátorem sama sebe, nebot platí že $x=y<=>y=x$.

18 Platí, že $x=y<=>\operatorname{NOT}(x<>y)$.

19 Operátor je silně restriktivní v př́ípadě, že jedním argumentem je konstanta, tj. výsledkem je malá podmnožina tabulky.

20 Operátoru se přiřazuje funkce odhadu selektivity.

Výše uvedené operátory stále nestačí k tomu, aby se nad sloupcem s vlastním typem mohl vytvořit index. Každý datový typ musí mít definovanou alespoň jednu třídu operátorů, což je v podstatě seznam operátorư doplněný o jejich sémantický význam. Kromě operátoru je potřeba určit tzv. podpưrnou funkci $F(a, b)$, jejíž parametry jsou klíče a výsledkem celé číslo $(a>b=>F(a, b)=1 ; a=b=>F(a, b)=0 ; a<b=>F(a, b)=-1)$.

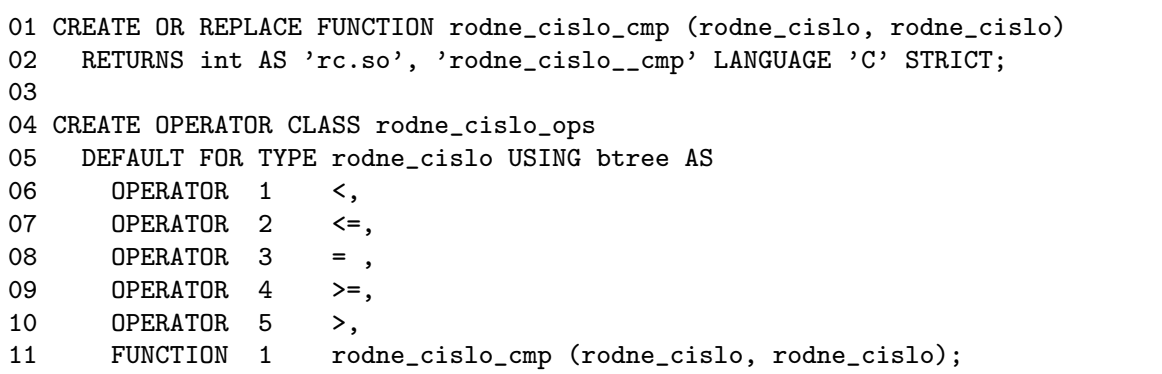

Komentáře:

06 Strategie 1 má význam menší než.

07 Strategie 2 má význam menší rovno než.

08 Strategie 3 má význam rovno.

09 Strategie 4 má význam vetší rovno než.

10 Strategie 5 má význam větší než.

11 Určení podpůrné funkce. 


\section{Ukázka použití PostGISu}

OpenGIS předpokládá uložení dat do klasických databázových tabulek. Nicméně k tomu, aby tyto tabulky dokázali přečíst GIS aplikace je nutné do datového schématu přidat dvě systémové (z pohledu OpenGIS) tabulky.

geometry_columns obsahuje informace o sloupcích geometrii geoprvků,

spatial_ref_sys obsahuje informace o souřadnicových systémech používaných systémem.

01 create table user_locations (gid int4, user_name varchar);

02 select AddGeometryColumn ('db_mapbender', 'user_locations', 'the_geom', '4326', 'POINT', 2);

03 insert into user_locations values ('1', 'Morissette', GeometryFromText ('P0INT (-71.060316 48.432044)', 4326));

\section{Komentáře:}

01 vytvoření tabulky faktů (feature table)

02 do tabulky user_location přidá sloupec s názvem the_geom (následně přidá do tabulky geometry_columns nový rrádek s metadaty o sloupci the_geom)

03 Plnění tabulky daty

Kromě plnění datových tabulek pomocí SQL př́kazů PostGIS obsahuje nástroj pro import datových (shape) souborů, tzv. shape loader. Díky němu je možné importovat data v několika formátech. Namátkou podporované formáty jsou Shape, MapInfo, DGN, GML.

K urychlení operací prováděných nad prostorovými daty lze použít prostorový index. PostgreSQL podporuje několik typů indexů, pro GIS lze použít (ve verzi 8.2) formáty GIST a GIN.

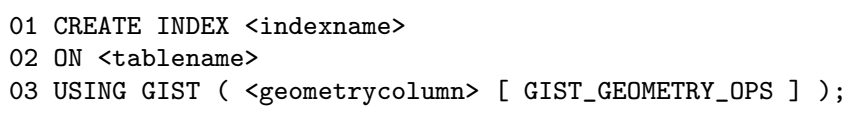

Komentáře:

03 GIST_GEOMETRY_OPS určuje výše zmíněnou třídu operátorů.

\section{Analýza obsahu distribuce PostGIS 1.2.1}

Struktura adresáře:

- ./ - Sestavovací a instalační skripty

- ./lwgeom - Zdrojový kód knihoven

- ./java/ejb - Podpora EJB Java

- ./java/jdbc - JDBC ovladač pro PostgreSQL rozšířený o podporu GIS objektů

- ./java/pljava - PostgreSQL PL/Java rozšířená o prostorové objekty

- ./doc - Dokumentace

- ./loader - Programy zajištujující konverzi ESRI Shape souborů do SQL (resp. PostGIS) a inverzní transformaci PostGIS dat do Shape souborů (pgsql2shp a shp2pgsql) 
- ./topology - Počáteční implementace modelu topology

- ./utils - Pomocné skripty (aktualizace, profilace)

- ./extras - Kód, který se nedostal do hlavního stromu (WFS_locks, ukázka wkb parseru)

- ./regress - Regresní testy

Závislosti:

- proj4 - knihovna realizující transformace mezi projekcemi

- geos - knihovna implementující topologické testy (PostgreSQL je třeba překládat $\mathrm{s}$ podporou $\mathrm{C}++$ )

Typ LWGEOM nahrazuje původní typ GEOMETRY PostGISu. Oproti němu je menší (data jsou uložená binárně - pro $\operatorname{POINT}(0,0)$ je to úspora z 140 bajtů na 21 bajti̊), podporuje $1 \mathrm{D}$, 2D, 3D a 4D souřadnice, interně vychází z OGC WKB typu a také jeho textová prezentace je OGC WKB. Typ LWGEOM nahradil předchozí typ GEOMETRY ve verzi 1.0. LW znamená Light Weight (vylehčený). Interně v PostgreSQL se používá identifikátor PG_LWGEOM. Hodnoty se serializují rekurzivně, za hlavičkou specifikující typ a atributy se serializují vlastní data.

Jádro PostGISu je schované v implementaci typu LWGEOM. Jako parser je, v prostředí UNIX obvyklý, použitý generátor překladačů Lex a yacc (konkrétně jejich implementace Bison). Syntaxe je určena v souborech wktparse.lex (lexikální elementy, klíčová slova, čísla) a wktparse.y (syntaktické elementy)

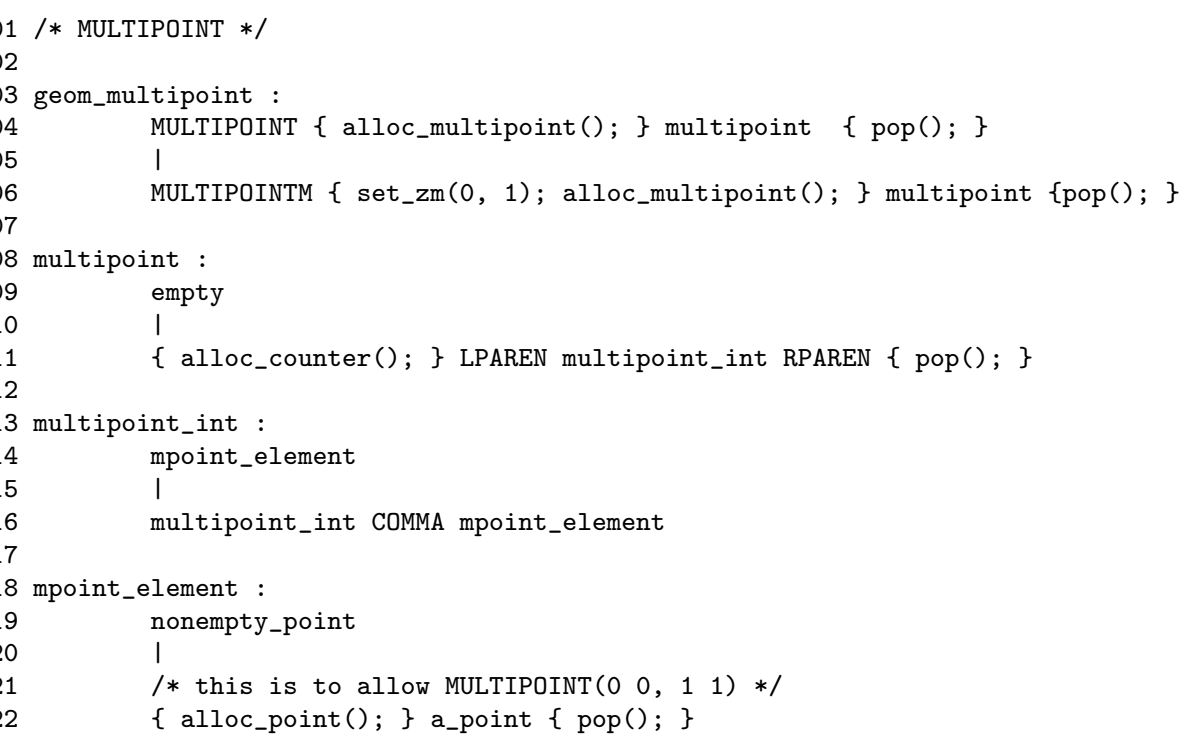

Komentáře:

03 Povoleným zápisem je MULTIPOINT seznam nebo MULTIPOINTM seznam.

08 Seznam může být prázdný nebo je posloupností čísel uzavřený v závorkách.

13 Seznam je bud'to o jednom prvku nebo seznam a čárkou oddělený element.

16 Rekurzivní definice seznamu. 
22 a_point je 2D 3D 4D hodnota zapsaná jako posloupnost n čísel oddělených mezerou.

Serializace a deserializace načteného syntaktického stromu je řešena v souboru lwgeom_inout.c.

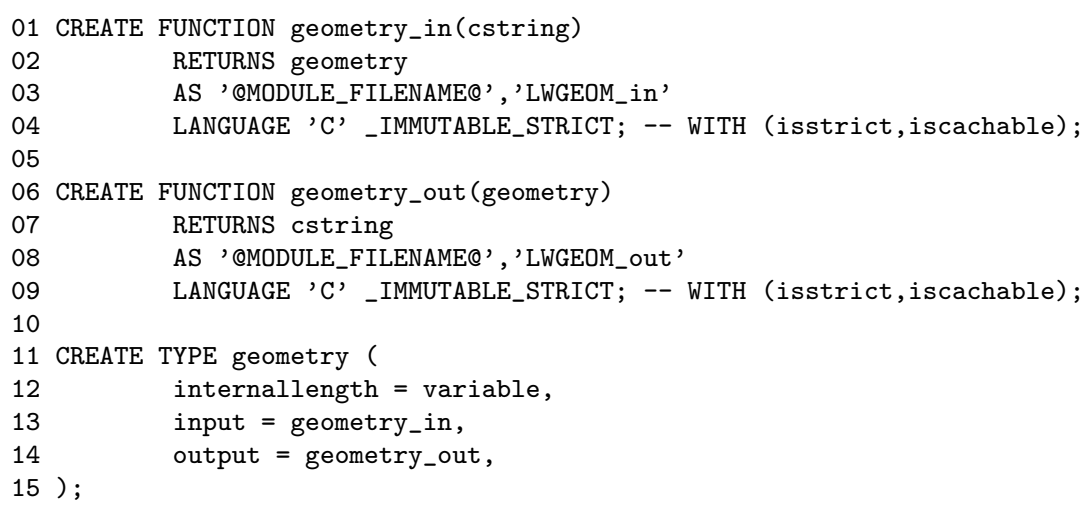

Definice typu geometry je v souboru lwpostgis.sql.in spolu s definicemi dalších desítek databázových objektů. Zcela zásadní jsou tabulky spatial_ref_sys a geometry_columns.

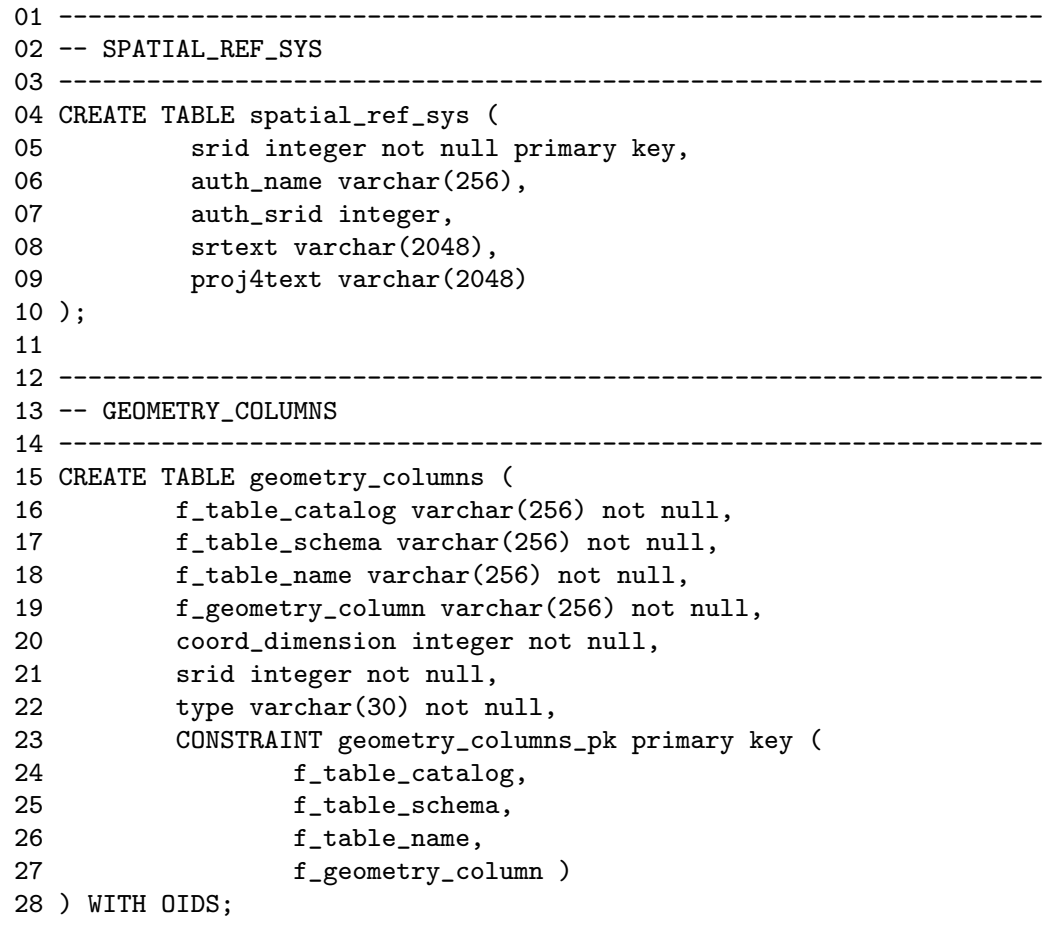

Řada funkcí PostGISu jsou realizována v jazyce PL/pgSQL. Což je jazyk SQL procedur v prostředí PostgreSQL vycházející z PL/SQL fy. Oracle (který vychází z prg. jazyka ADA). Je to celkem logické, díky integraci SQL jsou SQL př́kazy zapsány úsporně a čitelně.

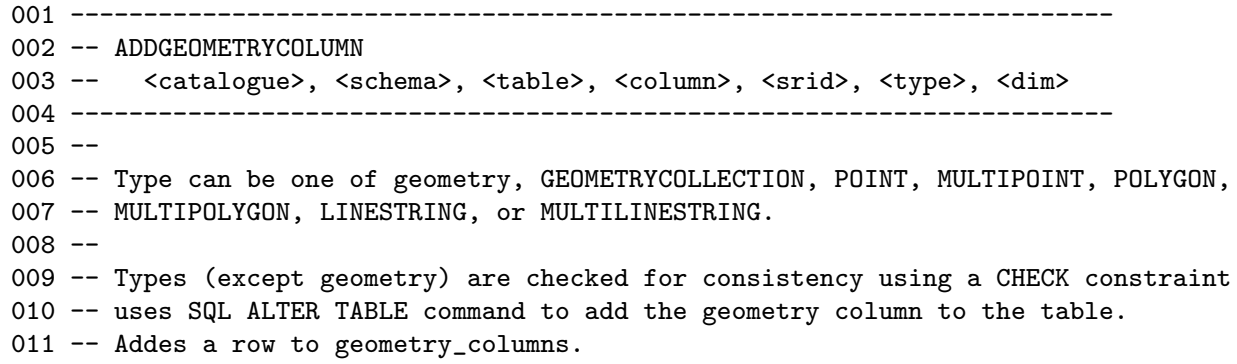




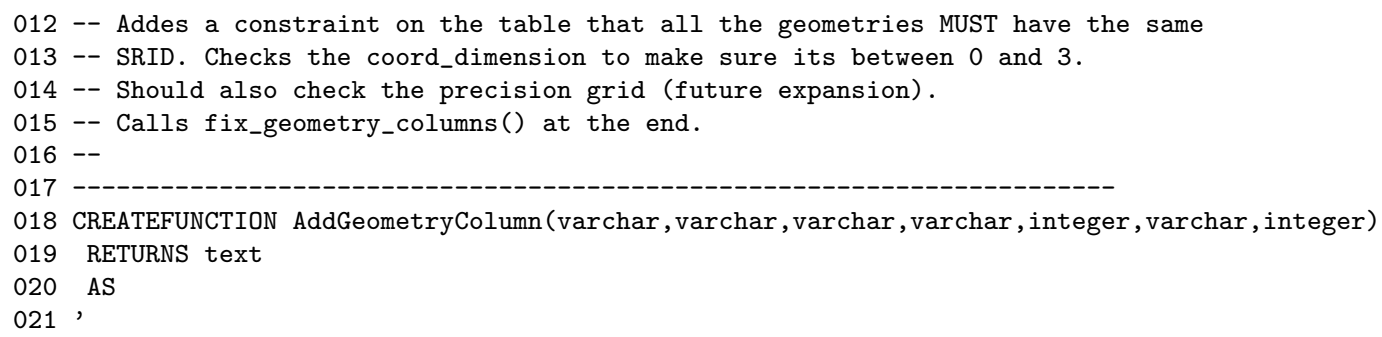

Komentáře:

018 Tento zdrojový kód se v PostGISu zpracovává ještě preprocesorem, takže na první pohled neplatné klíčové slovo CREATEFUNCTION je správné. Důvodem je potřeba jedné verze zdrojových kódů použitelných pro různé verze PostgreSQL, kdy mezi nejstarší verzí 7.4 a nejnovější 8.2 je zřetelný rozdíl v možnostech a i v zápisu uložených procedur. Jinak tyto verze od sebe dělí tři roky. Přestože oficiálně nejstarší podporovaná verze je 7.4, v kodu je řada odkazů na verzi 7.2.

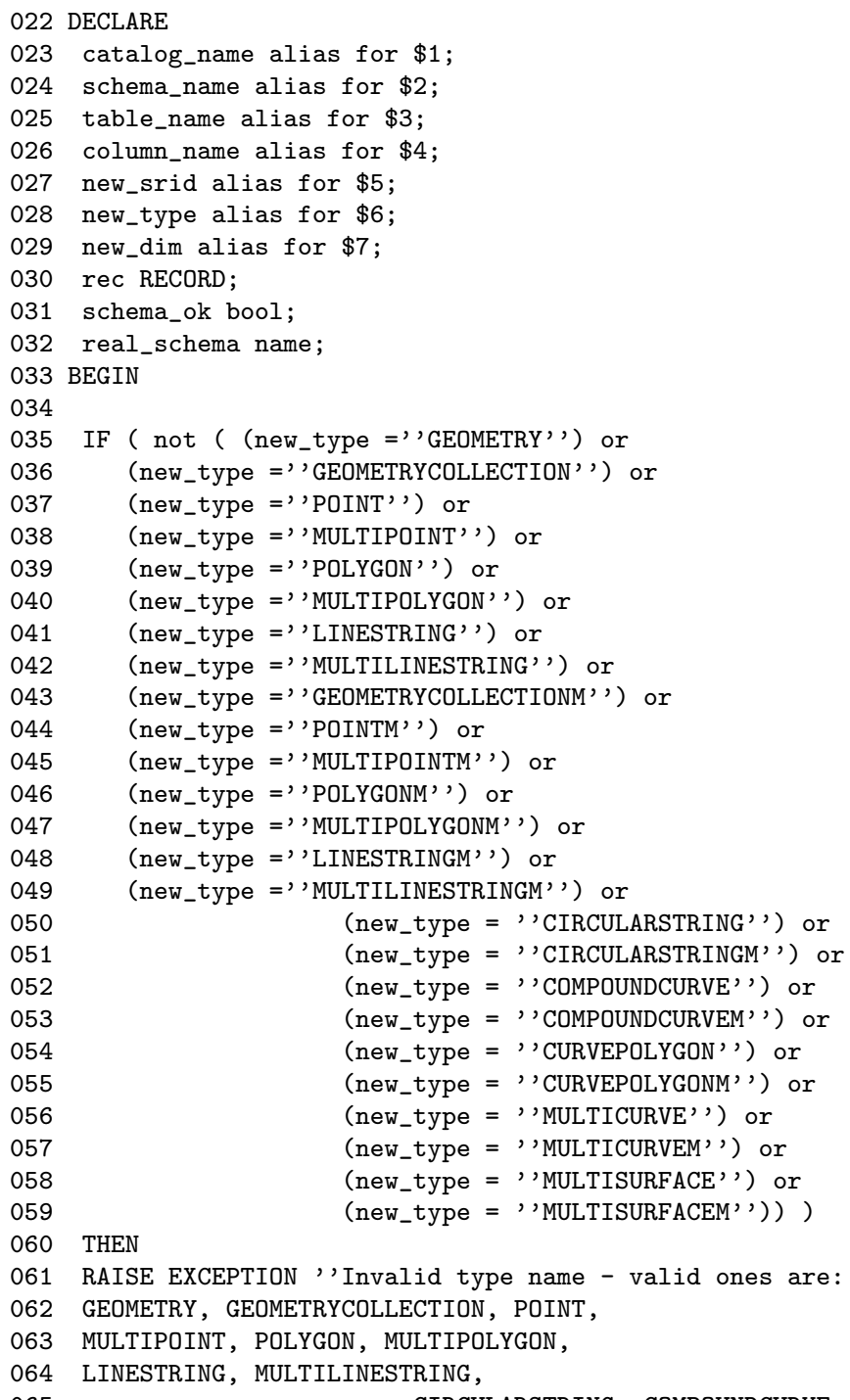




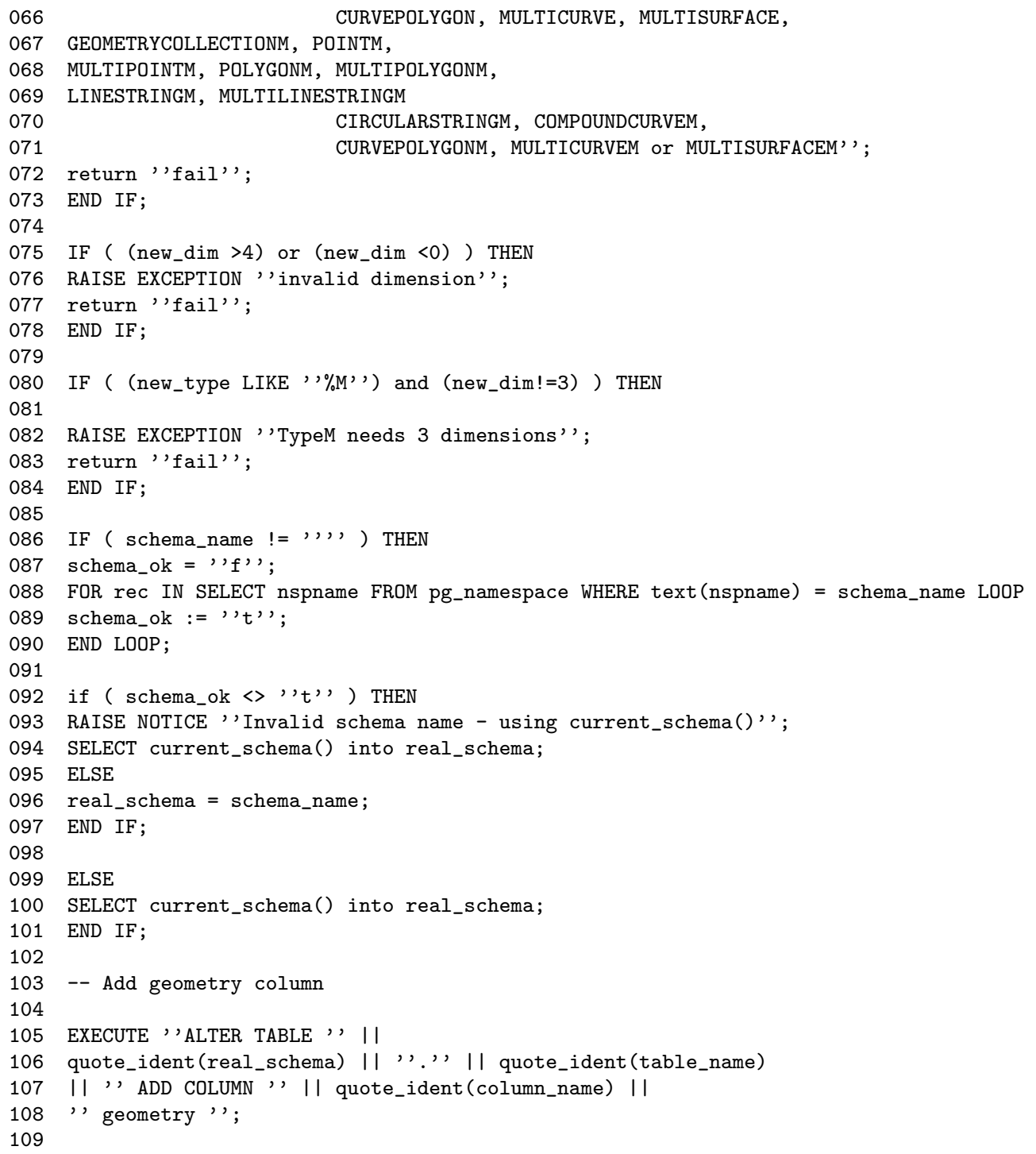

Komentáře:

105 Prostřednictvím dynamického SQL přidává sloupec do cílové tabulky faktů.

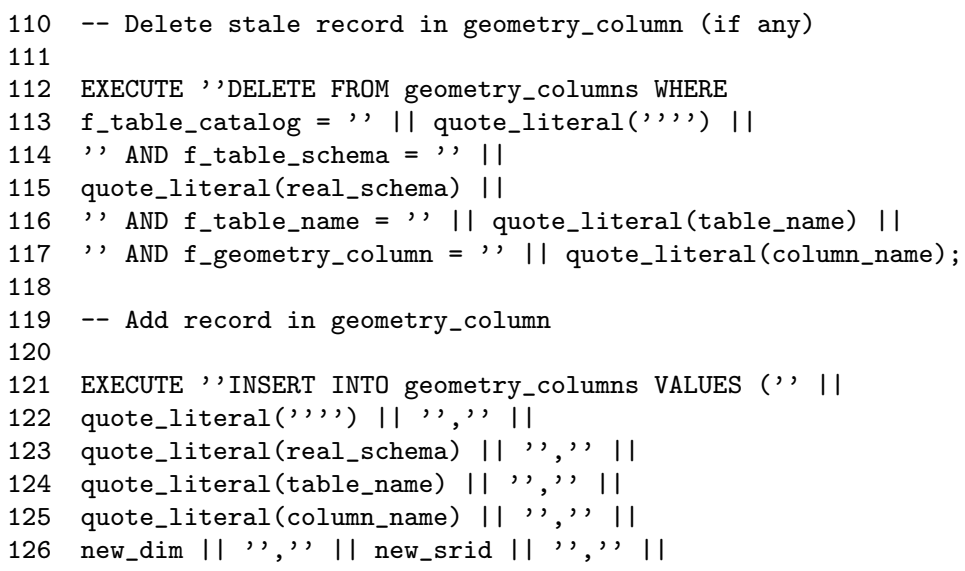


quote_literal (new_type) II' ')', ;

128

Komentáře:

112 Prostřednictvím dynamického SQL ruší sloupec, pokud byl takový, v tabulce metadat geometry_columns.

121 Prostřednictvím dynamického SQL vkládá metadata o sloupci do tabulky geometry_columns.

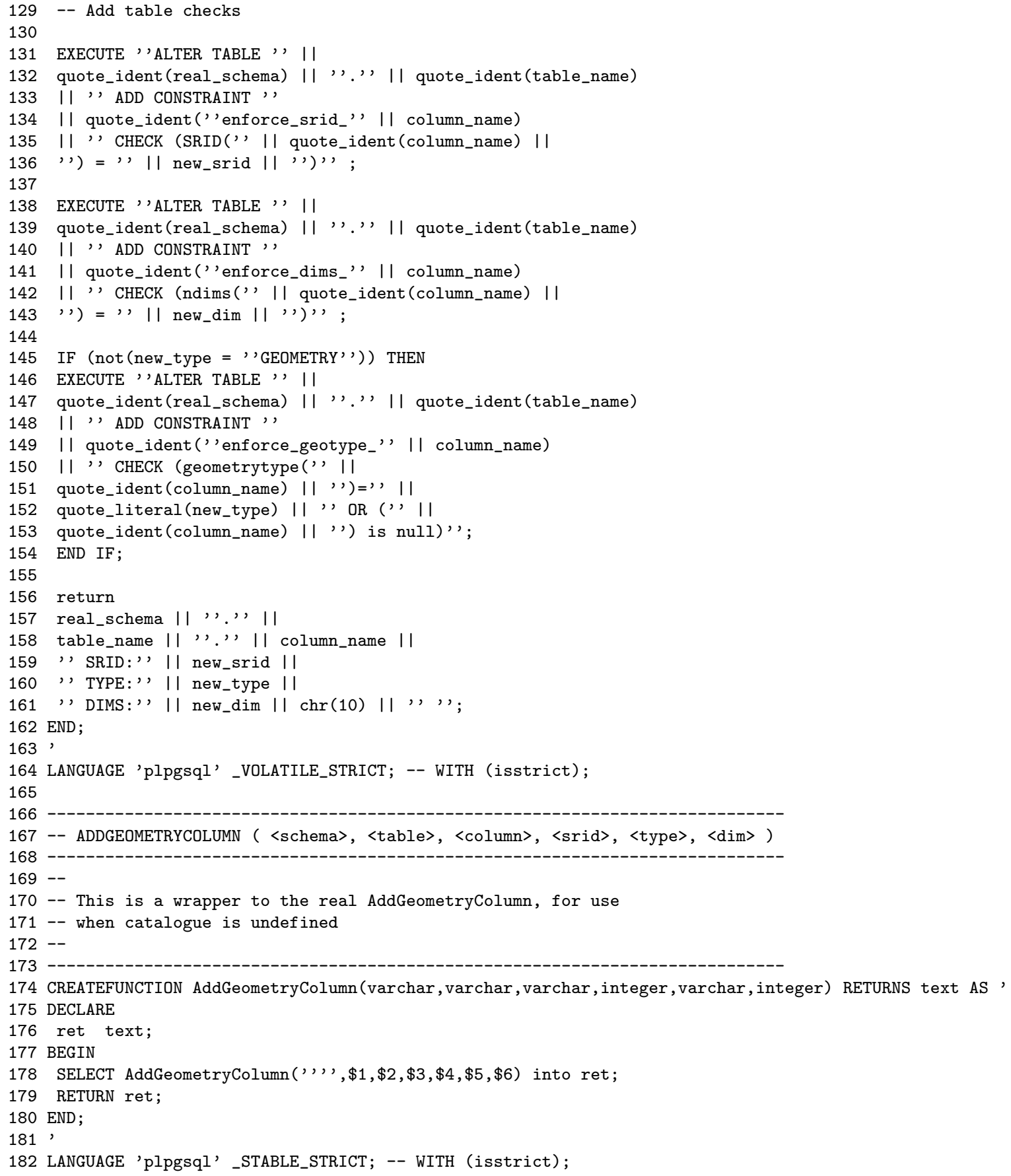




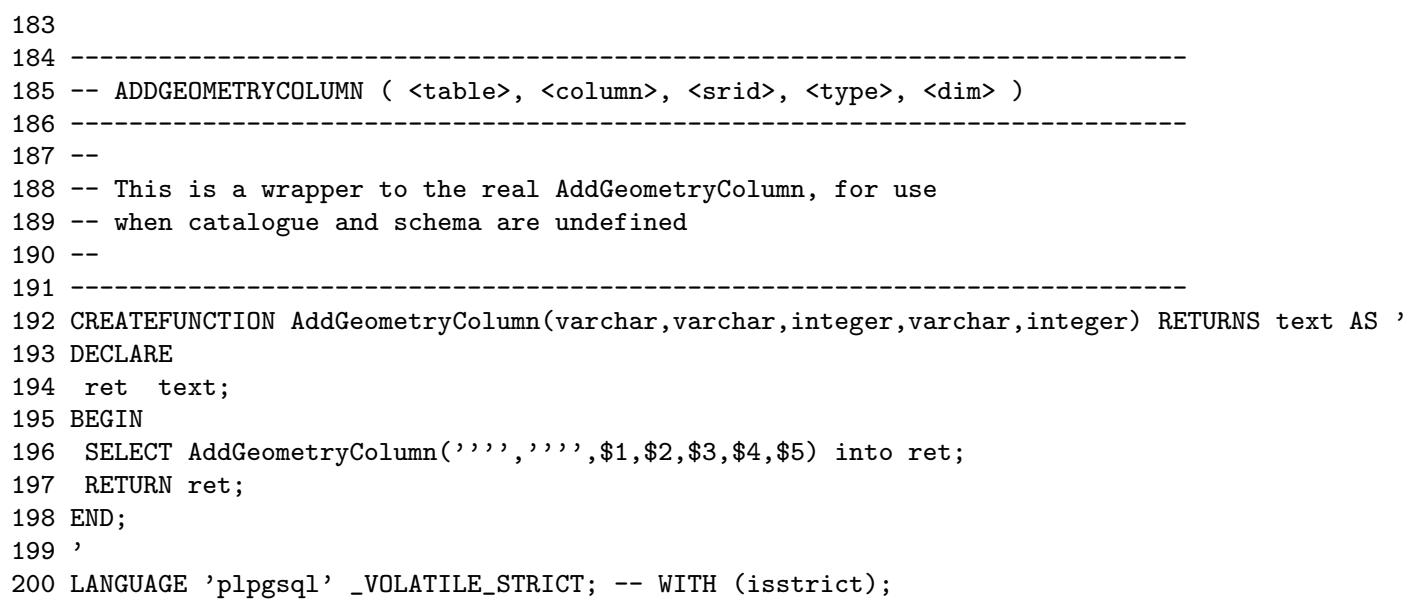

Komentáře:

174 Přetížení funkcí (tj. existuje více funkcí stejného jména s různými parametry) se v PostgreSQL (dle standardu ANSI) používá také k náhradě nepodporovaných volitelných parametrů. Funkce definované na řádcích 174 a 192 se používají v případě, že chybí hodnoty parametrů katalog a schéma. V ANSI SQL se nepoužívá termín databáze, ale katalog, který obsahuje jemnější dělení na jednotlivá schémata.

Zdrojový kód ESRI ArcSDE podporovaná podmnožiny SQL/MM funkcí je v souboru sqlmm.sql.

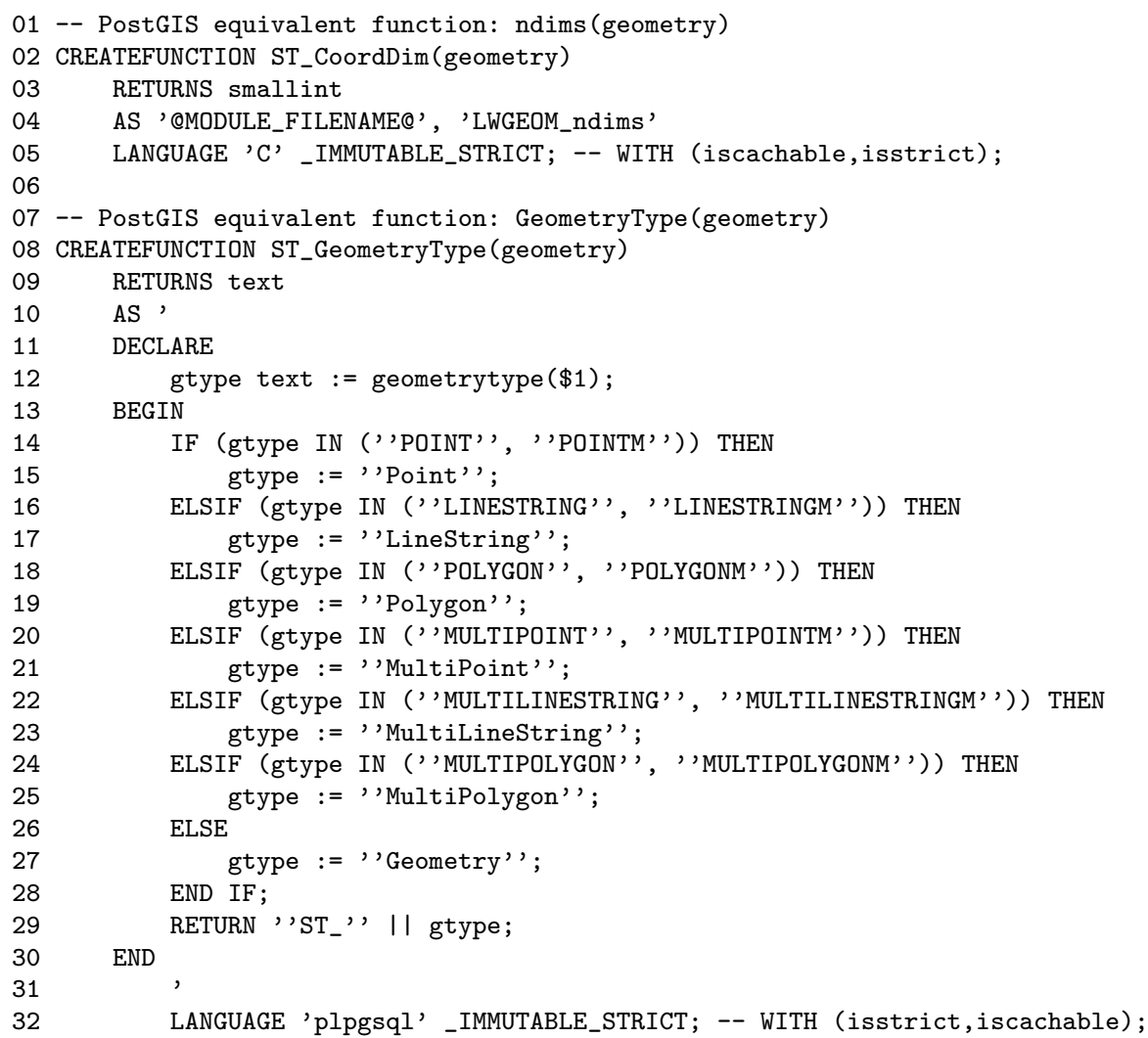

Komentáře: 
02 Vytvoření synonyma pro PostGIS funkci.

08 Zapouzdření PostGIS funkce kódem v plpgsql. V tomto případě se stírá rozdíl mezi typy MULTIPOINT a MULTIPOINTM (analogicky u dalších typů).

\section{Řešení výkonných funkcí v PostGISu}

Kromě vlastní implementace datových typů PostGIS obsahuje implementaci pomocných funkcí nad prostorovými daty. Následující př́́klady jsou funkce z lwgeom_functions_basic.c, které mohou sloužit jako vzor pro vytváření vlastních funkcí.

Funkce LWGEOM_makepoint se používá pro vytvoření 2D bodu na základě zadaných souřadnic.

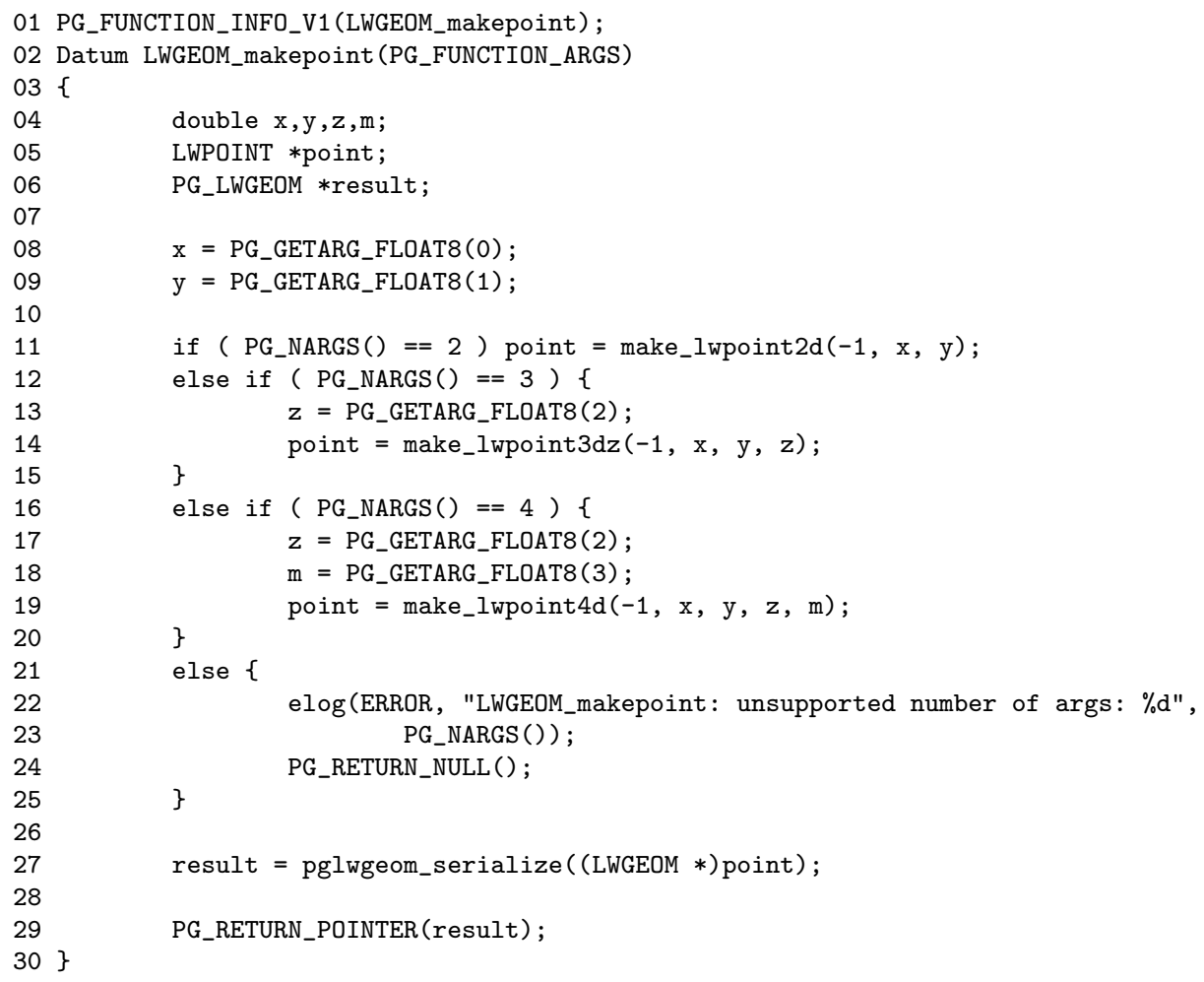

Komentáře:

01, 02 Standardní záhlaví funkce pro v1 volající konvenci

08, 09 Získání prvních dvou argumentů typu float8

11 Pokud počet argumentů funkce je roven dvěma, volá se externí funkce make_lwpoint2d, jinak se zjištuje počet argumentů a podle něj se volá odpovídající verze externí funkce.

22 Funkce elog se používá pro vyvolání výjimky, pokud je level ERROR. V případě, že level je NOTICE, zobrazí ladící hlášení.

24 Kód za elog(ERROR,...) se již neprovádí. V tomto případě PG_RETURN_NULL() slouží k utišení překladače ohledně zobrazení varování.

27 Serializace objektu do typu PG_LWGEOM. 
29 Výstupem z funkce je ukazatel na serializovanou hodnotu objektu, provede se konverze na typ Datum.

SQL registrace této funkce vypadá následovně:

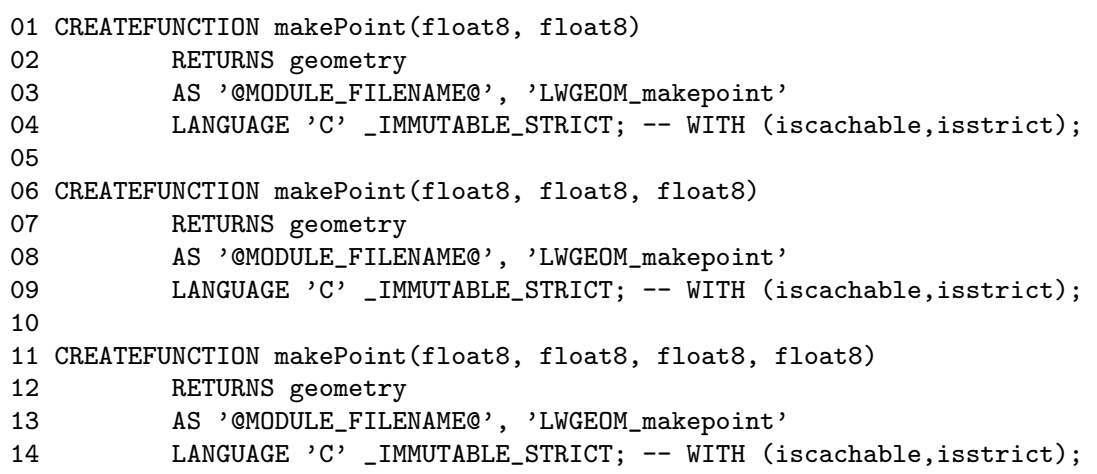

Komentáře:

01, 06, 11 Tato implementace je ukázkou přetížené funkce (s různým počtem parametrů), kdy všechny varianty této přetížené funkce sdílí jednu funkci implementovanou v jazyce C.

Funkce LWGEOM_inside_circle_point slouží k určení, zda-li je bod uvnitř nebo vně kruhu.

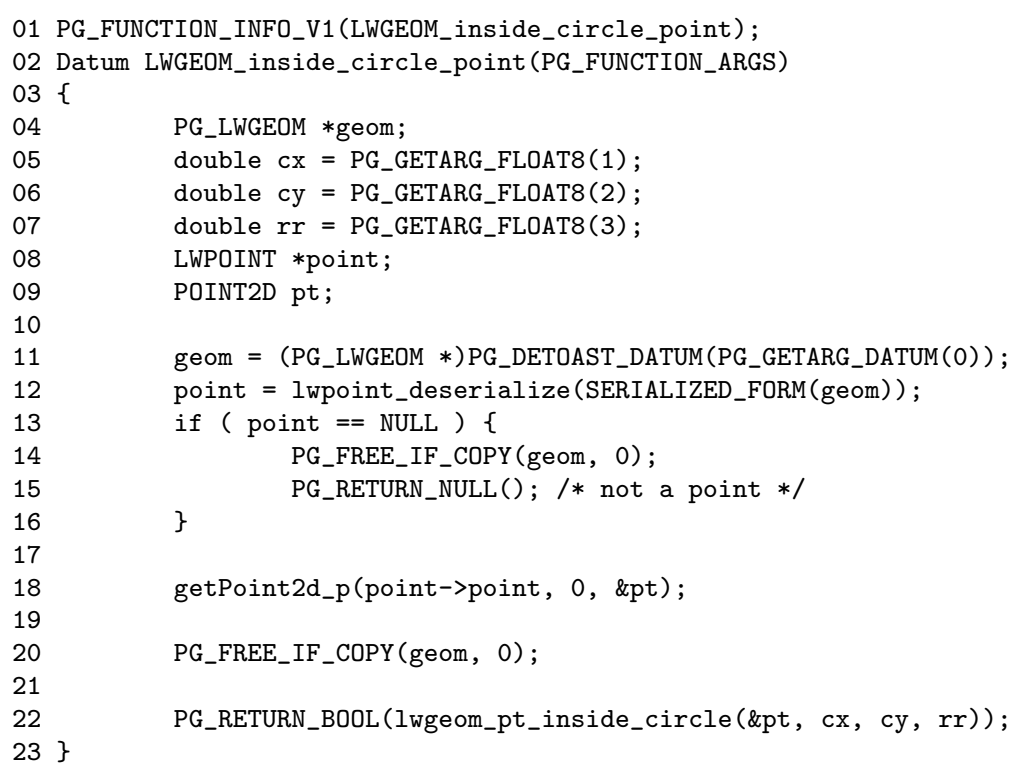

Komentáře:

11 Z TOAST hodnoty musíme získat serializovanou hodnotu typu PG_LWGEOM. TOAST je pro uživatele databáze (nikoliv pro vývojáře) transparentní mechanismus zajištujujicí kompresi a uložení serializovaných řetězců delších než $2 \mathrm{~KB}$. PostgreSQL interně používá datové stránky o $8 \mathrm{~KB}$ a žádná do databáze uložená hodnota (vyjma tzv. BLOBu) nemůže tuto velikost přesáhnout. Toto omezení se obchází právě metodou nazvanou TOAST, kdy se delší hodnoty dělí a ukládají do speciální tabulky do více řádků po maximálně $2 \mathrm{~KB}$ ).

12 Deserializace typu point. 
14 Bezpečné uvolnění paměti (celá řada typů se přenáší hodnotou, a tudíž je nelze chápat jako ukazatele a nelze dealokovat pamět na kterou by se odkazovaly).

18 Konverze typu LWPOINT na typ POINT2D.

22 Vrácení návratové hodnoty jako výsledku volání funkce lwgeom_pt_inside_circle.

Definice funkce lwgeom_pt_inside_circle (measures.c):

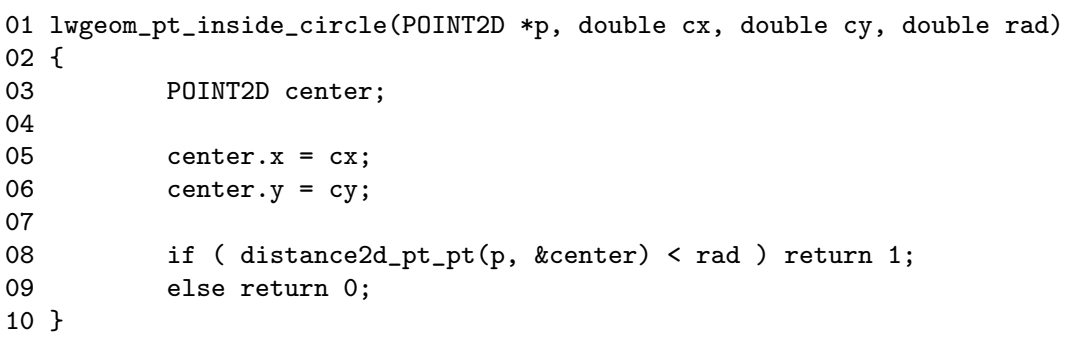

Funkce LWGEOM_inside_circle_point je registrována SQL př́ikazem:

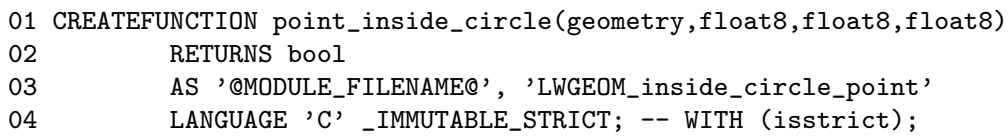

\section{Podpora indexu typu GiST v PostGISu}

Indexy typu R-tree jsou specifické právě pro prostorová vícedimenzionální data (a pro ně byly navrženy). Aktuální verze PostgreSQL nabízí již další generaci této třídy databázových indexů a to tzv. GiST (Generalized Search Tree) indexy. Jejich princip je stejný, širší je ale jejich uplatnění. GiST indexy se v PostgreSQL používají pro fulltext, indexování obsahu polí, vlastní podporu hierarchických dat a také samozřejmě pro geometrické typy.

Jak již bylo zmíněno, R-tree index předpokládá, že indexovaná data budou mít minimálně dvě dimenze. Index má stromovou strukturu, a každý nekoncový uzel obsahuje jednak odkaz na své potomky a hlavně geometrii nejmenšího pravoúhlého n-rozměrného tělese obsahujícího všechny potomky.

GiST je aplikační rozhraní, které umožňuje implementaci libovolného typu indexu: B-tree, Rtree. Výhodou GiST indexů je možnost vytvoření doménově specifických indexů vázaných na vlastní typy vývojářům znalým doménové oblasti bez toho, aby se nutně staly databázovými specialisty (Rozhodně ale implementace GiST indexu nepatří mezi triviální programování). Ukázkovým příkladem je použití GiST indexu v PostGISu. Kritériem, které se použije pro rozhodování, zda-li použít B-tree index nebo GiST index jsou operace, které chceme urychlit indexem. Pokud nám postačuje množina binárních operátorů $<,=,>$, pak je na místě uvažovat o B-tree indexu. V opačném případě nezbývá než použít GiST index, který je obecnější než B-tree index.

Prostorové indexy se dají použít i pro klasická data. Jednodimenzionální data se ale musí předtím převést na vícedimenzionální. Ukázkovým př́ípadem selhání jednodimenzionálního případu je následující příklad. Mějme databázi událostí popsanou časem zahájení (start_time) a časem ukončení (end_time). Pokud budeme chtít vypsat události, které probíhaly v určitém čase napíšeme dotaz s podmínkou

01 WHERE star_time $<t$ AND end_time $>(t+n)$ 
Indexace sloupců start_time a end_time zcela jistě pomůže, nicméně v tomto př́padě mají indexy malou selektivitu (v průměru oba vrací polovinu řádků z tabulky). start_time a end_time jsou dvě jednodimenzionální řady, takže se celkem přirozeně nabízí chápat je jako jednu dvou dimenzionální řadu a předchozí podmínku transformovat do tvaru postaveného nad geometrickými operátory.

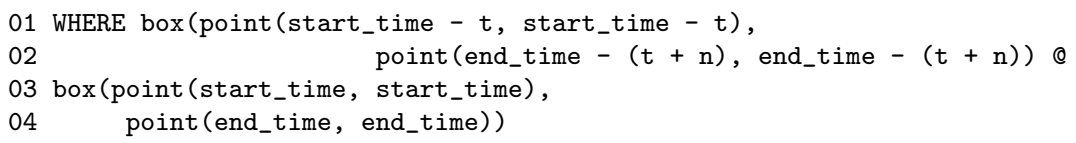

Komentáře:

01 Zápis není validní. Z důvodu čitelnosti neobsahuje nezbytnou konverzi z typu Date na celá čísla.

02 Operátor @ má význam kompletně obsažen.

\section{Popis a použití GiST indexu}

GiST index je vyvážený strom obsahující vždy dvojice klíč (predikát), ukazatel na data na hraničních uzlech stromu (listech) a dvojice tvrzení, ukazatel na potomky ve vnitřních uzlech stromu. Dvojice tvrzení, ukazatel se označuje jako záznam indexu. Každý uzel může obsahovat více záznamů indexu. Tvrzení (predicates) je vždy platné pro všechny klíče dostupné z daného uzlu. To je koncept, který se objevuje ve všech na stromech založených indexech. U již zmíněného R-tree indexu je tvrzením ohraničující obdélník obsahující všechny body (R-tree je index navržený pro prostorová data), které jsou dostupné z vnitřního uzlu.

Každý GiST index je definován následujícími operacemi:

Operace nad klíči - tyto metody jsou specifické pro danou třídu objektů a defacto určují konfiguraci GiST indexu (Key Methods): Consistent, Union, Compress, Decompress, Penalty, PickSplit

Operace nad stromem - obecné operace, které volají operace nad klíči (Tree Methods): Search (Consistent), Insert (Penalty, PickSplit), Delete (Consistent).

Operace nad klíči (v závorce smysl operace v případě prostorových dat):

Základní datovou strukturou používanou ve funkcích implementujících GiST index je GISTENTRY:

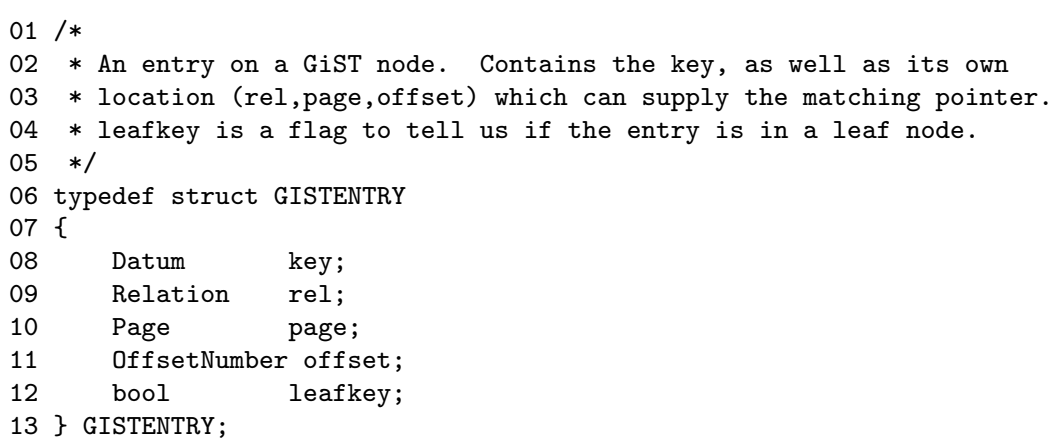

Komentáře: 
consistent Pokud v záznamu indexu je zaručeno, že tvrzení nevyhovuje dotazu s danou hodnotou, pak vrací logickou hodnotu nepravda. Jinak vrací logickou hodnotu pravda. Pokud operace nesprávně vrátí log. hodnotu pravda, pak tato chyba nemá vliv na výsledek, pouze ovlivní efektivitu algoritmu (true, pokud dochází k překryvu, jinak false).

union Pro danou množinu záznamů indexu vrací takové tvrzení, které je platné pro všechny záznamy v množině.

compress Převádí data do vhodného formátu pro fyzické uložení na stránce indexu (V případě prostorových dat se určí hraniční obdélník).

decompress Opak metody compress. Převádí binární reprezentaci indexu tak, aby s ní mohlo API manipulovat (načte se hraniční obdélník).

penalty Vrací hodnotu ve významu ceny za vložení nové položky do konkrétní části stromu. Položka je vložena do té části stromu, kde je tato hodnota (penalty) nejnižší (Zjištuje se, o kolik by se zvětšila plocha hraničního obdélníku).

picksplit Ve chvíli, kdy je nutné rozdělit stránku indexu, tato funkce určuje, které položky zůstanou na původní stránce, a které se přesunou na novou stranu indexu.

same Vrací logickou hodnotu pravda pokud jsou dvě položky identické.

09 Identifikátor tabulky

10 Identifikace datové stránky

11 Pozice na datové stránce

a

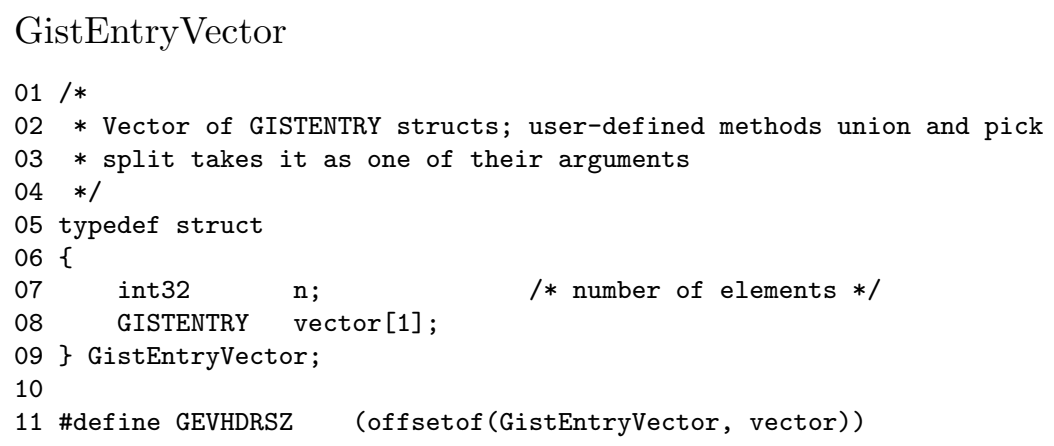

Následující příklad je ukázkou metody union, která vrací nejmenší možný obdélník pro všechny zadané body:

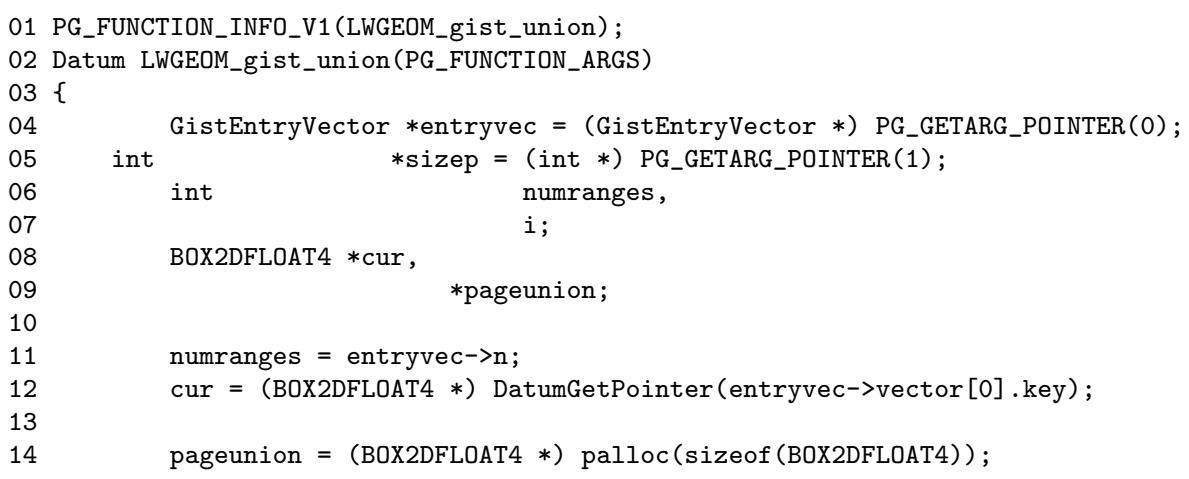




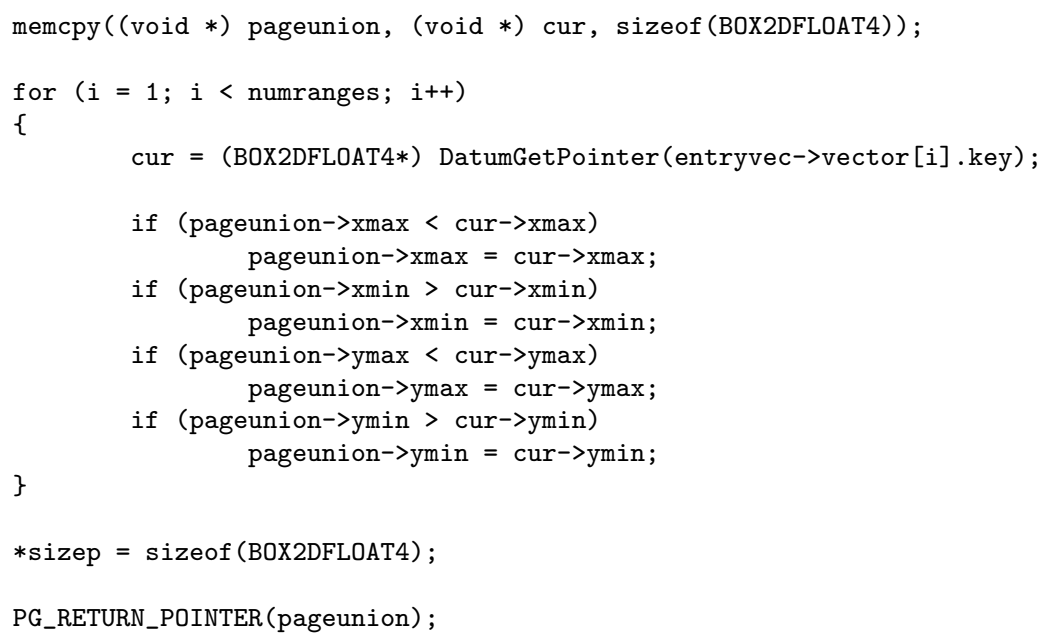

Komentáře:

04 První argument obsahuje ukazatel na GistEntryVector

05 Druhý argument obsahuje ukazatel na velikost vrácené datové struktury

14, 15 Vytvoření prostoru pro výstupní strukturu pageunion a její naplnění prvním prvkem vektoru.

12, 19 Naplnění struktury cur (iterace po prvcích GiST vektoru, který obsahuje prvky typu Datum (v tomto př́padě ukazatele na typ BOX2DFLOAT4)

21-28 Hledání nejmenšího možného obdélníka obsahujícího všechny zadané body

33 Předání ukazatele na výstupní strukturu

Každá funkce podporující GiST index se musí nejdříve zaregistrovat jako PostgreSQL funkce a potom všechny relevantní funkce ještě jednou objeví v registraci GiST indexu:

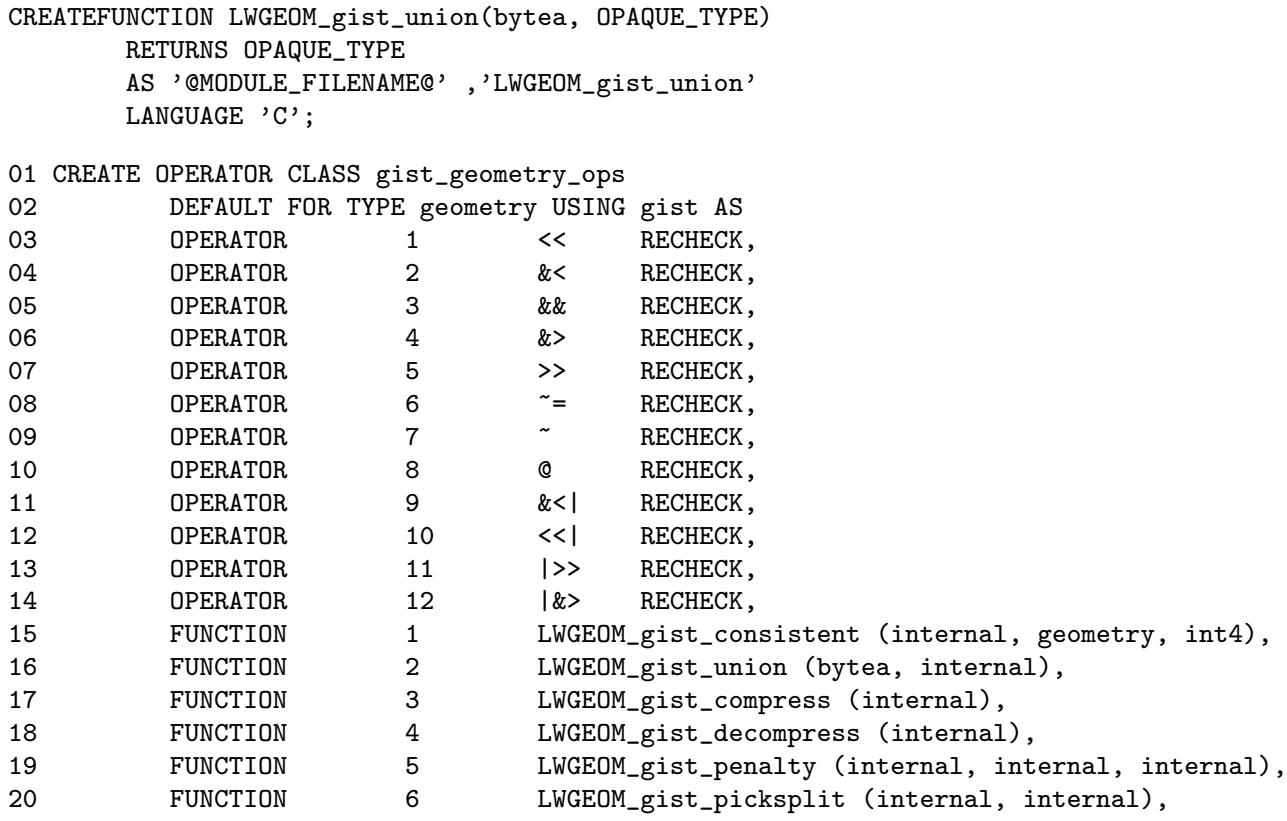


21 FUNCTION 2 LWGEOM_gist_same (box2d, box2d, internal); 1

01 CREATE OPERATOR CLASS gist_geometry_ops

\section{Závěr}

Cílem této práce bylo připravit podklady umožňující snažší orientaci v implementaci standardu OpenGIS v prostředí o.s. databázového systémy PostgreSQL - PostGIS. Nejdůležitější komponenty systému PostGIS byly popsány, zbytek nikoliv. Což ani nebylo cílem práce. Ačkoliv není pravděpodobné, že by někdo mohl navrhnout vlastní rozšsiŕrení PostGISu bez předchozích znalostí PostgreSQL, C a vlastních GIS aplikací, doufám, že díky této práci mohou vznikat další rozšîření postavené nad tímto, poměrně velice úspěšným produktem.

\section{Literatura}

- Správa časoprostorových dat v prostředí PostgreSQL/PostGIS, Antonín ORLÍK

- http://postgis.refractions.net/docs/

- Návrh a realizace UDF v C pro PostgreSQL ${ }^{1}$

- Access Methods for Next-Generation Database Systems²

- Spatial Data Management ${ }^{3}$

\footnotetext{
${ }^{1}$ http://www .pgsql.cz/index.php/N\%C3\%A1vrh_a_realizace_UDF_v_C_pro_PostgreSQL\#N .C3.A1vrh_vlastn.C3.ADch_datov.C3.BDch_typ.C5.AF

${ }^{2}$ http://citeseer.ist.psu.edu/rd/0\%2C448594\%2C1\%2C0.25\%2CDownload/http://citeseer.ist । .psu.edu/cache/papers/cs/22615/http:zSzzSzs2k-ftp.cs.berkeley.edu:8000zSz\%7Emar । celzSzdisszSzdiss.pdf/access-methods-for-next.pdf

${ }^{3}$ http://www.mapbender.org/presentations/Spatial_Data_Management_Arnulf_Christl/Spati | al_Data_Management_Arnulf_Christl.pdf
} 